\title{
Phyllodes Tumor of the Vulva: Report of Two Cases
}

\author{
Vulvanın Fillods Tümörü: Iki Olgu Sunumu
}

\author{
İrem Hicran ÖZBUDAK'1, Hampar AKKAYA², Bahar AKKAYA', Gülgün ERDOĞAN'', Hadice Elif PEŞTERELi'1, \\ Fatma Şeyda KARAVELi ${ }^{1}$
}

${ }^{1}$ Department of Pathology, Akdeniz University, Faculty of Medicine, ANTALYA, TURKEY, ${ }^{B}$ Başkent University, Faculty of Medicine, Alanya Hospital, ANTALYA, TURKEY

\begin{abstract}
Ectopic breast tissue can occur anywhere along the primitive embryonic milk line and can be the site of the same pathologic processes found in the normal breast. Phyllodes tumor is an extremely rare fibroepithelial neoplasm that occurs in ectopic breast tissue of the vulva. To date, only 8 cases of phyllodes tumor in the vulva have been reported in the literature. This paper presents two additional case of benign phyllodes tumor in the vulva. The first patient was a 43-year-old woman, presenting with a lesion on the left anterior mons pubis that had increased in size in the last three months. The second patient was a 50-year-old woman, presenting with a two-month history of a mass in the right labium majus. The patients underwent excisional biopsy. The histological examination of both specimens revealed a characteristic pattern of benign phyllodes tumor. In conclusion, the pathologists need to be aware that the lesion can occur in this location. Herein, the concepts about the histogenesis of phyllodes tumor in the vulva are discussed and a brief review of the previously reported cases is given.
\end{abstract}

Key Words: Vulva, Phyllodes tumor

\begin{abstract}
ÖZ
Ektopik meme dokusu ilkel embriyonik sütyolu boyunca herhangi bir yerde ortaya çıkabilir ve normal memede izlenebilen aynı patolojik durumlar ektopik meme dokusunda da görülebilir. Fillods tümör vulvadaki ektopik meme dokusunda oluşan nadir bir fibroepitelyal neoplazidir. Literatürde bugüne kadar 8 olgu bildirilmiştir. Bu makalede literatüre ek olarak iki ayrı vulvar fillods tümör vakası sunulmuştur. İlk olgu, sol ön mons pubiste boyutu son üç ayda artış gösteren bir lezyon ile kliniğe başvurmuş 43 yaşında kadın hastadır. İkinci olgu 50 yaşında kadın hasta olup, iki aydır varolan sağ labium majusta kitle ile başvurmuştur. Mevcut lezyonlara eksizyonel biopsi yapılmış ve örneklerin patolojisi benign fillods tümör ile uyumlu rapor edilmiştir. Sonuç olarak, fillods tümörün vulva lokalizasyonunda da karşılaşabilecek bir antite olduğu unutulmamalıdır. Burada, vulvar fillods tümörün histogenezi ile ilgili kavramlar tartışılmış ve olgularımız daha önce bildirilen olgular eşliğinde sunulmuştur.
\end{abstract}

Anahtar Sözcükler: Vulva, Fillods tümörü

\section{INTRODUCTION}

Phyllodes tumor is an uncommon fibroepithelial neoplasm that accounts for less than $1 \%$ of all breast tumors. It is also known to occur in various other anatomical sites, including the vulva, prostate and axilla (1-9). The tumor has epithelial and stromal components. It grows as leaf-like projections into the glandular lumens. The stroma is usually hypercellular, typically with periglandular condensation. The grade is defined by the stromal atypia as benign, low or high grade phyllodes tumor (10).

Ectopic breast tissue can occur anywhere along the primitive embryonic milk line bilaterally, extending from the axilla to the groin. Such ectopic breast tissue can be the site of the same physiological and pathological processes found in the normal breast. The occurrence of phyllodes

(Turk Patoloji Derg 2013, 29:73-76)

Received : 03.02.2011 Accepted : 10.03.2011 tumor arising within vulva is extremely rare (1-7). Herein, we report two cases of benign phyllodes tumor originating in ectopic breast tissue of the vulva.

\section{CASE REPORTS}

Case 1

A 43-year-old woman was referred for evaluation of a lesion on the left anterior mons pubis. The patient had noted the appearance of slightly raised, firm nodule a year ago and the lesion gradually began to increase in size in the last three months. She had no history of malignancy or breast disease. The patient underwent excisional biopsy of the lesion.

\section{Case 2}

A 50-year-old woman presented with a two-month history of a painless, non-tender subcutaneous mass in the right

Correspondence: İrem Hicran ÖZBUDAK

Department of Pathology, Akdeniz University, Faculty of Medicine,

ANTALYA, TURKEY

E-mail: iremhicrang@hotmail.com Phone: +90 505289848 
labium majus. She had been postmenopausal for about 1 year. There was no history of prior malignancy or breast disease. The lesion was excised surgically.

\section{Pathologic Findings}

The tumor of the first case was elastic, oval with a whiteyellow cut surface and included cleft-like spaces. It measured $4.7 \times 3.5 \times 2.3 \mathrm{~cm}$ (Figure 1). The tumor of the second case was $3.2 \times 2 \times 1.2 \mathrm{~cm}$ in size. Macroscopically, it was oval and lobulated with a glistening white-yellow cut surface (Figure 2).

The histological examination of both specimens revealed biphasic tumor composed of bilayered ductal component and fibroblastic stroma (Figure 3A, B). The epithelium was hyperplastic in both tumors, and focal squamous metaplasia with keratinization was detected in the sections of the first case (Figure 3C). The stroma was prominent and interrupted by leaf-like spaces lined by epithelium. The stromal cellularity was marked in focal areas adjacent to the intratumoral ducts. No mitotic activity or cellular atypia were found. The entire specimens of both cases were sectioned and blocked, but no normal breast tissue was identified.

\section{DISCUSSION}

The breasts develop from ectoderm at about the fourth to sixth week of the embryogenic period. The thickened ectoderm bilaterally forms mammary ridges or "milk lines" on the ventral surface of the embryo, extending from the axilla region to the groin. The breast tissue continues to develop in the normal pectoral region of the milk line, with regression of the remainder of the mammary ridges. As a classical knowledge, it is accepted that failure of this regression leads to the development of ectopic breast tissue (11).

The true incidence of ectopic breast tissue is not known. It is found much more frequently in women. Although the tissue is present at birth, it does not become prominent until influenced by female sex hormones at puberty, pregnancy, or lactation. The axilla and vulva are the most frequent sites of presentation (11).

A variety of benign and malignant lesions have been reported in ectopic breast tissue. These include intraductal papilloma, fibroadenoma and adenocarcinoma (11). Phyllodes tumor is extremely rare in the vulva and only 8 cases have been previously reported in the literature. These patients have usually presented with a gradually enlarging mass, but also a long-standing stable mass and cyst were encountered. The most common anatomical sites were the labium majus and minus, but the interlabial sulcus and mons pubis were reported once. They were usually solitary except the case reported by Tbakhi et al. (1). All the tumors were microscopically identical to its counterpart in the breast, with a characteristic biphasic phenotype of phyllodes tumor and leaf-like configuration (1-7). The differential diagnosis of phyllodes tumor of the vulva includes the

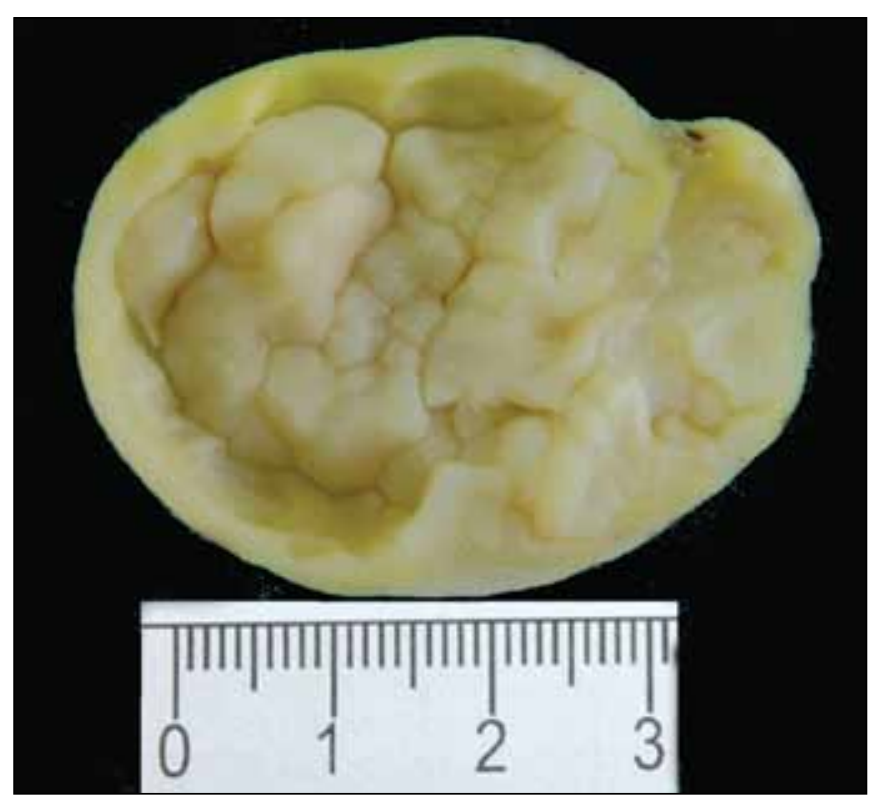

Figure 1: The tumor was oval in shape with a white-yellow cut surface and included cleft-like spaces.

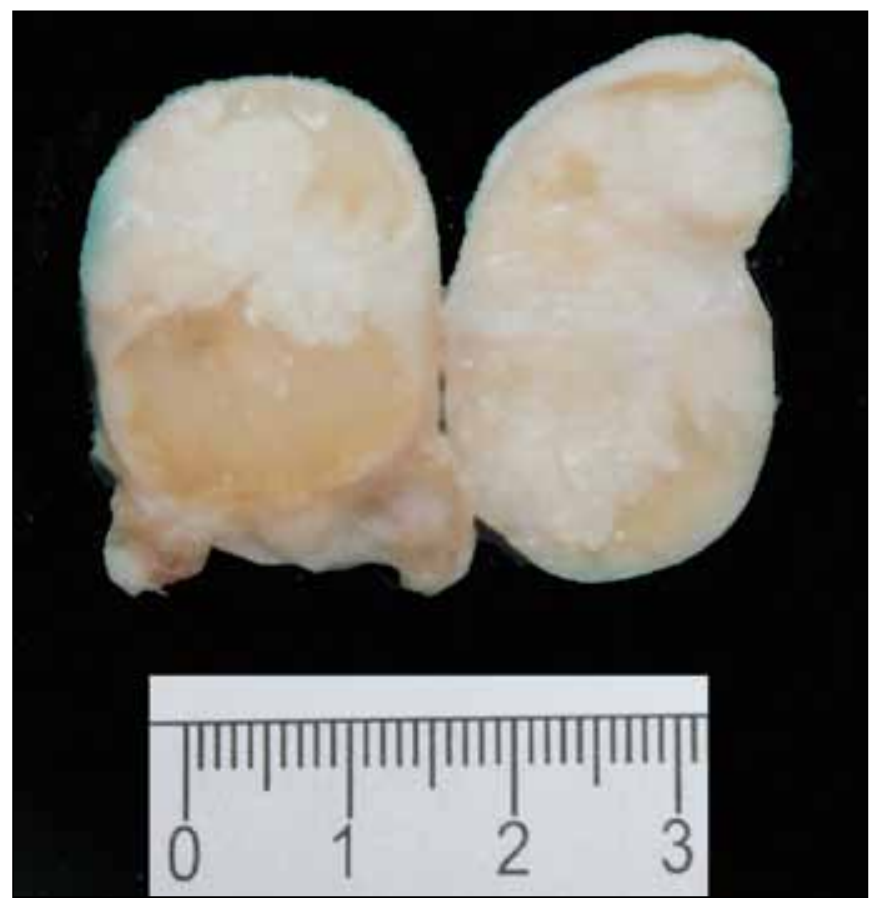

Figure 2: The tumor was oval and lobulated with a glistening white-yellow cut surface. 

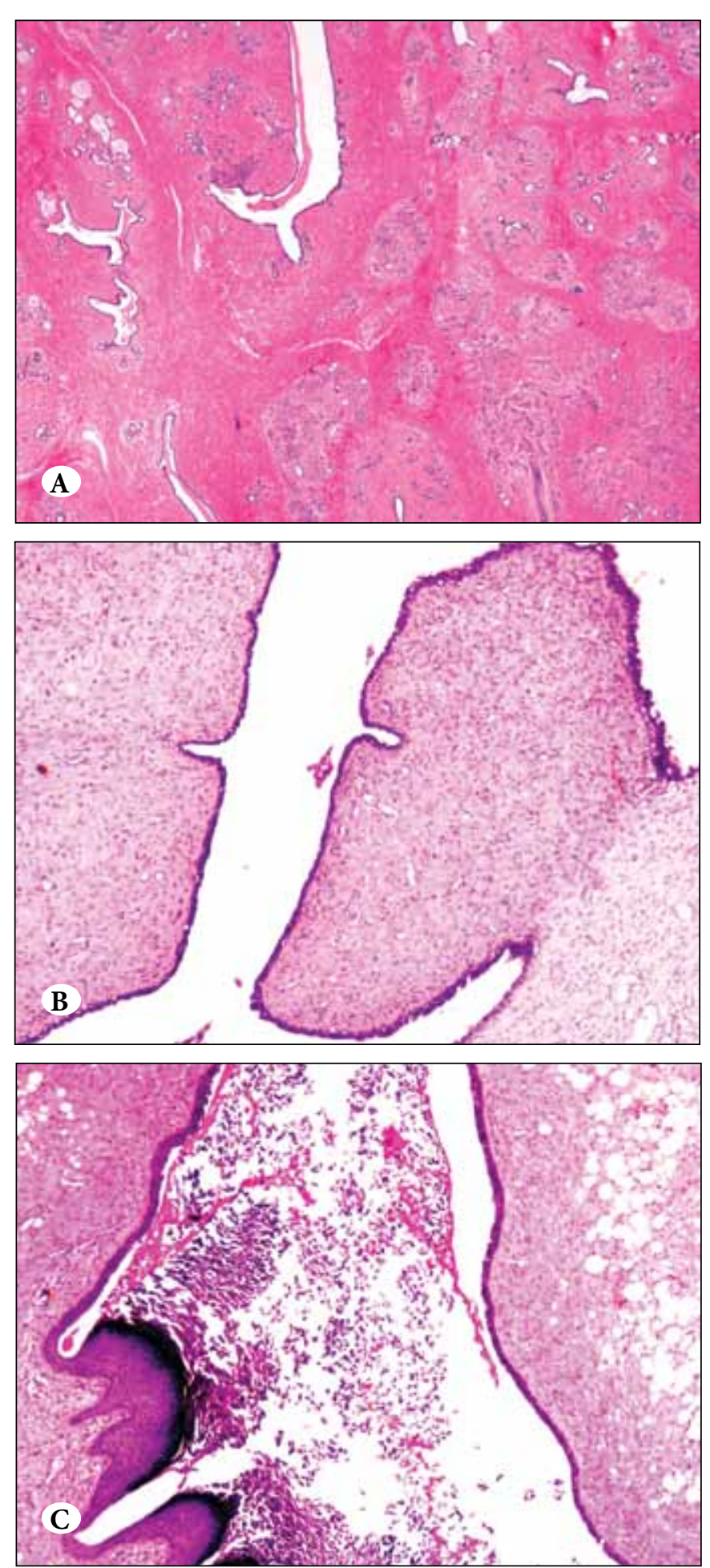

Figure 3: (A-B) The tumor was composed of fibroblastic stroma interrupted by leaf-like spaces lined by epithelium (A: H\&E, x2, B: H\&E x10), (C) The epithelium was hyperplastic and had focal areas of keratinizing squamous metaplasia (H\&E, x10). biphasic tumors such as chondroid syringoma and mixed Müllerian tumor (10). The behavior of phyllodes tumor of the vulva is difficult to predict by histology alone, as the existing data is limited. During follow-up, the reported cases were unremarkable except for one borderline case and two cases with recurrence (1-7).

Some authors believe that mammary ridges never reach the vulva during their embryogenesis. Van der Putte described a distinctive variant of cutaneous glands (12). In normal histology, the sebaceous glands are predominantly present on the medial surface of the labia majora with or without hair follicles. Apocrine and eccrine sweat glands are generally only found in hair-bearing areas (13). Van der Putte preferred to call these lesions mammary-like anogenital sweat glands rather than ectopic breast tissue that combine features of eccrine and apocrine glands (12). These glands showed the capacity to branch into lobuli and to form acini-like mammary glands. They were reported to take place in the interlabial sulcus, the paramedian area of the perineum and around the anus. Existence of normal breast tissue or mammary-like glands around the lesion may give some clues about histogenesis. Unfortunately, there was no non-neoplastic tissue around the lesions in our cases. Similarly, in the literature, many of this kind of lesions have been included into this category without the presence of co-existing normal glands.

In conclusion, histopathological findings could not help for determining the histogenesis of these lesions. Whatever the histogenesis, the present tumors were histologically identical to benign phyllodes tumor of the breast and only 8 cases of phyllodes tumor in the vulva have been reported in the literature.

\section{REFERENCES}

1. Tbakhi A, Cowan DF, Kumar D, Kyle D: Recurring phyllodes tumor in aberrant breast tissue of the vulva. Am J Surg Pathol 1993,17:946-950

2. Mannan AA, Kahvic M, Aziz AH: Phyllodes tumor of the vulva: Report of a rare case and review of the literature. Am J Dermatopathol 2010, 32:384-386

3. Chulia MT, Paya A, Niveiro M, Ceballos S, Aranda FI: Phyllodes tumor in ectopic breast tissue of the vulva. Int J Surg Pathol 2001, 9:81-83

4. Tresserra F, Grases PJ, Izquierdo M, Cararach M, FernandezCid A: Fibroadenoma phyllodes arising in vulvar supernumerary breast tissue: Report of two cases. Int J Gynecol Pathol 1998, 17:171-173 
5. Giger OT, Lacoste E, Honegger C, Padberg B, Moch H, Varga $Z$ : Expression of the breast differentiation antigen NY-BR-1 in a phyllodes tumor of the vulva. Virchows Arch 2007, 450:471-474

6. Mariappan MR, Lagera JE, Fadare O, Sibley RK: A 69-year-old woman with a vulvar lesion. Phyllodes tumor of the vulva. Arch Pathol Lab Med 2006, 130:11-12

7. Heffernan TP, Sarode VR, Hoffman B, Lea J: Recurrent phyllodes tumor of the vulva: A case report with review of diagnostic criteria and differential diagnosis. Int J Gynecol Pathol 2010, 29:294-297

8. Saleh HA, Klein LH: Cystosarcoma phyllodes arising synchronously in right breast and bilateral axillary ectopic breast tissue. Arch Pathol Lab Med 1990, 114:624-626

9. Schapmans S, Van LL, Cortvriend J, Beelaerts W, Van EP: Phyllodes tumor of the prostate. A case report and review of the literature. Eur Urol 2000, 38:649-653
10. Bellocq JP, Magro G: Fibroepithelial Tumours. In Tavassoli FA, Devilee P. (Eds): World Health Organization Classification of Tumours. Pathology and Genetics. Tumours of the Breast and Female Genital Organs. Lyon, IARA Press, 2003, 99-101

11. Velanovich V: Ectopic breast tissue, supernumerary breasts, and supernumerary nipples. South Med J 1995, 88:903-906

12. van der Putte SC: Mammary-like glands of the vulva and their disorders. Int J Gynecol Pathol 1994,13:150-160

13. Wilkinson E J, Hardt NS: Vulva. In: Mills SE. (Ed): Histology for Pathologists. 3rd ed., Philadelphia, Lippincott Williams and Wilkins, 2007, 983-998 